\section{Marzena Szewczuk-Steppień}

(iD) https://orcid.org/0000-0001-8080-9317

Faculty of Economics and Management Opole University of Technology m.szewczuk-stepien@po.edu.p

\section{Magdalena Jurczyk-Bunkowska}

D https://orcid.org/0000-0002-4066-3605

Faculty of Economics and Management

Opole University of Technology

m.jurczyk-bunkowska@po.edu.pl

\title{
The concept of a civic technology tool for empowering social innovations
}

Accepted by Editor Ewa Ziemba | Received: September 26, 2018 | Revised: February 10, 2019; May 9, 2019; September 30, 2019; December, 10, 2019 | Accepted: December 11, 2019.

\section{Abstract}

Aim/purpose - The main objective of this study is to present a concept of an IT tool supporting management of a social innovation process.

Design/methodology/approach - The concept was preceded by an analysis of more than 30 leading internet platforms supporting innovation processes.

Findings - As a result of the review of the literature and the analysis of internet platforms supporting innovation processes the assumptions of IT tool have been defined. The idea of building the civic technology tool to increase participation in creating a new solution has emerged. Each stage of social innovation development is characterised by individual requirements, it coincides with the participation of different stakeholders. The IT tool concepts which have been proposed include the specification of the social innovation process and show the frame for knowledge collection during the process of new social solution development.

Research implications/limitations - The concept of IT tool is a starting point for further research into the issue of using crowd knowledge to empower the cycle of social innovation development.

Originality/value/contribution - The scope of this paper fills in the research gap that exists in area of supporting the social innovation processes by IT tools. The proposed concept should be the basis for further work in the use of civic technology in the cycle of social innovation development. In particular, the area of citizens' participation, e.g. creating the methods and procedures of knowledge acquisition and assessment.

Keywords: civic technology, Web 2.0 platform, social innovations, participatory model, crowdsourcing.

JEL Classification: L31, M15, 035, R11.

Cite as: Szewczuk-Stępien, M., \& Jurczyk-Bunkowska, M. (2020). The concept of a civic technology tool for empowering social innovations. Journal of Economics \& Management, 39(1), 149-167. https://doi.org/10.22367/jem.2020.39.08 


\section{Introduction}

Social innovations play a key role in the sectors where the existing solutions fail, are outdated or do not allow for opportunities that arise in the surroundings to be properly taken advantage of (Rawhouser, Cummings, \& Newbert, 2019). These include: education, health care, environmental protection, public finance, public and social services, as well as urban planning. The emergence of new, more efficient, sustainable or fairer solutions in this area have had a positive impact on the improvement of the population's quality of life and consequently, on the development of the region. The stimulation of entrepreneurship and innovation is therefore important for local, regional and national authorities, and at the heart of the Europe 2020 strategy.

One may notice that in Poland the number of people who want to participate in social activity and who can highly contribute to it is growing (Łabędź, 2016). Unfortunately, the current channels of communication are no longer sufficient (Acik, 2013). One of the reasons for this is that the changing lifestyles and forms of communication have, in practice, excluded many young people from creating value for the communities in which they live. Working in cities outside their region of residence and the multitude of duties mean that they do not participate in public consultations. Overcoming these barriers and using their potential is possible thanks to modern IT tools. They will enable the participation of a wider community in decision-making processes and thus increase the amount of available knowledge and strengthen the community's identification with the region.

Civic technology is a term used to describe information technology that supports various aspects of civic life and public institutions. It is not limited to digital management or e-administration, but also aims at supporting civic involvement (Gilman, 2016). It can and should be used to deepen democratic relations between the citizens and their country. In order to effectively perform their tasks, local governments should want and know how to acquire new ideas, use the potential of the Web and learn from the experience of the citizens. The local government in the Opole region looks for creative and affordable solutions to specific societal problems where the IT tools are not implemented. The spread of the Internet and the ubiquity of mobile phones enable more people to work toward solving pressing social and environmental problems. Additionally, the literature emphasises the advantages of the collaborative process in building new knowledge, involving both knowledge sharing and creation as well as linking them to IT solutions (Blazevic \& Lievens, 2008). Unfortunately, there is a lack of citizen experience in participation in social innovation processes with the use of IT tools. 
The aim of the paper is to present the concept of an IT tool which supports the creation and implementation of social innovations. Such a tool should enable and encourage the exchange of knowledge among community of a region. It is also crucial to focus joint efforts on the most important issues in terms of quality of life and therefore on achieving the synergy effect. It is assumed that the implementation of the proposed tool will support the processes of social innovations. However, in the long run, it will also contribute to the growth of entrepreneurship by systematically stimulating the activity of the inhabitants and directing their efforts toward searching for knowledge and identifying opportunities for change.

The literary background of this issue is discussed in the next section of the paper. The description includes a social innovation process model and participation model. The third section shows the research methodology based on the observation of two kinds of IT platforms: one dedicated to innovation processes (1) and the other used by a regional government for supporting two-way contact with its citizens (2). The second platform included more than twenty examples. The research findings, both literary and empirical, are presented in section four. They served as the basis for developing the concept of the tool for supporting the implementation of social innovation processes. The fifth section presents the structure of the IT platform for supporting social innovation processes in Poland, also discussing it and justifying the proposed solutions. The paper ends with a conclusion indicating the directions of further studies that should be carried out in order to implement the presented concept.

\section{Theoretical background}

Innovations are new solutions implemented into practice connected with obtaining a specific value (Tidd \& Bessant, 2013). They may concern known and well-identified problems but also those that have emerged recently. Among the many definitions of innovations focusing on the degree of their innovativeness or process nature, it is worth noting the one that highlights the economic and social aspect. It describes innovation as new solutions that are better than the ones previously used by people which affect their living conditions (Fagerberg, 2004). Innovations are created as a result of processes implemented at the level of an individual, a working team, an organisation, or jointly on more than one of these levels (Anderson, Potočnik, \& Zhou 2014). It should be noted that they are not only the result of research and development activities but are a multidimensional process with many different sources based on complex interactions be- 
tween individuals, the organisation and the institutional environment (Tomlinson, 2010). This applies equally, and perhaps even to a greater extent, to social innovations.

\subsection{Social innovations and the process of their development}

Social innovations have their roots in civic society. Nowadays, it is more than just a protest movement. More and more often it is about cooperation with national and international public and private organisations to create changes in the surroundings (Saebi, Foss, \& Linder, 2019). Social innovations are defined as a new, orientated combination or configuration of social practices, thereby distinguishing them from technological innovations implemented in the public domain (Howaldt, Kopp, \& Schwarz, 2015). Social innovations are driven by the need to fulfil the needs of the inhabitants of a given area (Mulgan, 2007). Their identification is the first of a series of activities comprising the process where the implementation leads to the realisation of a social innovation. The three-step model for this process includes defining the social challenge, identifying the unfulfilled needs, and exploring the opportunities for fulfilling them (Bates, 2012). However, reality shows that it can be much more complex. This is why this paper is based on a six-step model of the process of innovation creation Figure 1 (Murray, Caulier-Grice, \& Mulgan, 2010).

Figure 1. Six stages model of social innovation

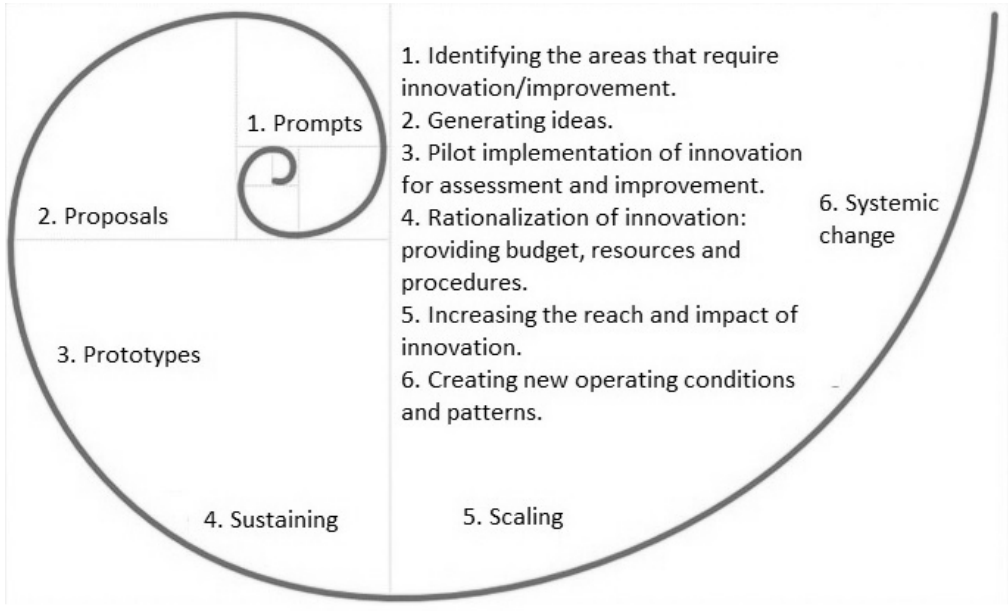

Source: Murray et al. (2010). 
It points to the links between the identified steps, the possibility of them overlapping, or their implementation in various orders. This causes the process of social innovations, much like other innovation processes, to be iterative and non-linear. The road from identifying the need by generating an idea to diffuse the innovation consists of gradually developing the knowledge (Olejniczuk-Merta, 2015). The early stages of the process of social innovations where experimental nature requires a high level of knowledge and great creativity are particularly complex and uncertain. Thus many ideas are abandoned in the early stages of the process but even these produce a certain effect in the form of new knowledge and learning experiences by the individuals involved (Grimm, Fox, Baines, \& Albertson, 2013).

People and their ability to combine different types of knowledge play a key role in managing innovation processes. Those who carry out innovation processes and, above all, those who manage them must have traits that enable them to operate effectively in conditions of high uncertainty. Such a role, in the case of social innovations, is performed by people involved in public life (Saebi et al., 2019).

\subsection{Use of the participatory management model to stimulate social innovations}

Nowadays, more often than ever, society is being invited to co-manage. Efforts are also being made to ensure that management, especially in local government units, is based on multisectoral and multidimensional cooperation (Foote Whyte, 1991). This cooperation is based on mutual trust and effective communication. The authorities are trying to be perceived by communities as supportive institutions. Society is encouraged to show interest in public affairs and to participate actively in the making of various decisions. Here, the role and efforts of local leaders should be noted and appreciated (Peter-Bombik \& Szczudlińska-Kanoś, 2015). Even if these people do not always find their place in the structures of government.

Following the direction for development taken in the European Union as set out in 'Europe 2020: A strategy for smart, sustainable and inclusive growth', a justification can be found for the need to apply the participatory model. Participation develops the ability to communicate, submit individual ideas, express one's opinions but, above all, it can strengthen the sense of co-responsibility. Tasks undertaken jointly by citizens, inhabitants and local institutions, which 
involve natural, human and financial resources in a well thought out way. Hence the possibility of creating space for social innovations corresponding to the unique character of the region (Estensoro, 2015).

Based on analyses of theoretical and empirical studies (Irvin \& Stansbury, 2004; O'Faircheallaigh, 2010; Sobol, 2015) we can single out many possible ways of working with the stakeholders in local development. These methods are diverse in nature and can be divided into the following kinds of activities (Szewczuk-Stępień, Adamska, \& Klemens, 2017):

- one-sided, according to the push algorithm, consisting of the sending of information by traditional or electronic mail, periodically distributing newsletters, leaflets, posting information and announcements on notice boards;

- engaging, through the use of interest and willingness to undertake activities, e.g. through regular meetings of working groups, periodic informal meetings, training sessions, presentations, workshops, the introduction of the so-called suggestion box, all in order to enable discussion and create a sense of influence;

- co-decision, according to the participatory model, i.e. involvement of stakeholders in decision-making, defining the basis for creation, and principles of implementation.

The effectiveness of the implementation of the participatory model of assumptions depends on commitment, responsibility and a sense of co-decisionmaking. Integration and cooperation toward the common good must not be a top-down process (O'Faircheallaigh, 2010). The internal strength of development underlies bottom-up initiatives (Szewczuk-Stępień et al., 2017). Bottom-up activation of human resources and utilisation of the assets of the given area may satisfy the needs of the community and lead to social and economic revival.

Studies on the use of the participatory model (in the process of creating local and regional strategic documents) have identified barriers in the use of traditional techniques (public consultations, individual interviews at the consultation desk, group coaching or civic meetings), such as: the lack of reliable and timely conveyed information, low awareness of the local community with regard to effectiveness of their activities, inability to involve some of the people due to their participation in other works or projects, lack of appropriate skills on the part of stakeholders, conflicting persons joining the initiative whose behaviour disrupts the climate of active cooperation (Acik, 2013; Szewczuk-Stępień et al., 2017). In this situation, it is of utmost importance to develop an opinion and a view of real cooperation as well as full involvement in the planning and decision-making among the stakeholders. These negative factors can be eliminated or significantly reduced by using IT tools. 


\section{Research methodology}

The study consists of two main parts: (1) a theoretical part that includes a review of existing literature and (2) an empirical part including an exploratory and a descriptive study of IT platform supported in innovation. A literature review was conducted with the purpose of mapping existing research in relation to theories, tools, and concepts for social innovation. It resulted in an overview of the main publications, research directions, and terminology used. The research methodology is presented in Figure 2.

Figure 2. Stages of research on concept of IT solutions aided the social innovation process

\section{Main research problem}

Q: How can IT solutions stimulate the development of social innovations?

\section{Literature research findings}

- model of social innovation development;

- participatory management model

- innovation process aided by IT platforms.

\section{Detailed research question}

Q1: What concepts and tools are used in the cycle of social innovation development?

Q2: What solutions stimulate participation of IT platform users in innovation processes?

\section{Empirical research findings}

- reliance on the concept of Open Innovation (Q1);

- use of crowdsourcing (Q1, Q2);

- cooperation between manufacturers and users which is initiated by a company in order to generate value for customers (co-creation) (Q1,Q2);

- use of big data analytics (Q1);

- systematic building of an innovation-oriented community through the use of 'gamification' mechanisms (Q2)

Empirical research findings are the results of observing more than 30 IT platforms aiding the innovation processes. Many of them are short-term projects that are not attractive to users in the longer term, for example mamzdanie.org.pl (I have my own opinion). Many of them 'die' after a few events, e.g. cyfrowademokracja.pl (digital democracy), www.konsultacje.soclab.org.pl (consultations), a platform to support the planning of conservation tasks for Natura 2000 areas: pzo.gdos.gov.pl. The research focused on platforms that work successfully for a few years. The main ones were: IdeaScale, Imaginatik, Spigit, 
Qmarkets, Hype, inno360 change.org, InnoCentive, Collective Awareness Platforms for Sustainability and Social Innovation (CAPS), Smart Citizen Platform, ManaBalss.lv, EngagingPlans, CitizenSpace, IdeaConnection, etc. IT platforms used by regional governance in Poland were also analysed, for example: Wrocławski Budżet Obywatelski (Wroclaw Civic Budget), and similar IT platforms in Kraków, Warszawa, Poznań, Łódź, or naprawmyto.pl (let's fix it) where citizens report infrastructure faults. Conducting the observation, the focus was on identifying common solutions used in platforms that have been growing in popularity over at least 2 years. The results of observation concerned the determination of good practices of the IT platform functioning.

\section{Research findings}

\subsection{Literature research findings}

The Internet and, in particular, the Web 2.0 technology which have been popular in recent years, have fundamentally changed the way knowledge is shared. Not only have users become recipients, but also authors of information, creating virtual communities and various types of networking. Thanks to the interactions that occur within this networking, information is processed (Sankowska, 2016). This processing consists of organising knowledge through the actions of many people as well as the collective solving of problems that exceed the capabilities of an individual person. In connection with the development of information technology, the use of collective intelligence - the ability of virtual communities to increase the level of knowledge and expert competence of their members through cooperation and debates conducted on a large scale - it is becoming more and more effective. Collective co-creation of knowledge consists of voluntary cooperation of many users who comment on, expand and supplement the published knowledge. These mechanisms are employed in a practical application of the open innovation concept, the essence of which is to implement innovation processes using external resources when creating new notions, concepts and ideas (Chesbrough, 2012).

In order to achieve the expected results of knowledge exchange through platforms based on the Web 2.0 technology, it is necessary to build a community a group of individuals who voluntarily improve the knowledge, e.g. by sharing their experiences (Wenger, 2000). This is probably the easiest in the case of non-commercial innovations, the benefits of which serve the society as a whole, and not individuals (Phills, 2008). 


\subsection{Empirical research findings}

Nowadays, in Poland, local authorities are using social media more and more to communicate with the citizens. However, generally this is only onesided communication and thus it does not provide an opportunity to create knowledge. An opportunity to express one's own opinion is essential for an individual in order to feel important enough to want to express their opinion and share their knowledge. Therefore, civic technology is using the potential of a mechanism called crowdsourcing more frequently. It is based on the "wisdom of the crowd' concept. Its essence is to attract a crowd of users to collaborate in order to build a long-term artefact beneficial to the entire community (Doan, Ramakrishnan, \& Halevy, 2011). A community that is large and diverse is able not by consensus, but through the aggregation of individual ideas - to better assess the reality, propose a creative solution to a problem and create a new innovative concept (Surowiecki, 2004). Development of crowdsourcing, which falls within the open innovation concept, entails development of virtual communities and the creation of Web 2.0 that allows the Web to be used as platforms through which content and applications are constantly modified by all users (Kaplan \& Haenlein, 2010).

Analysis of IT tools supporting the processes of innovations has shown that crowdsourcing is the mechanism used by most of them. An example is the IdeaScale platform (https://ideascale.com) which effectively supports the creation processes of social and commercial innovations. It is cloud-based software that serves more than 25,000 customers and 4 million users. It allows organisations to benefit from community feedback by collecting ideas, holding votes in favour or against them and allowing commenting on the submitted ideas or proposals. This solution is used by large American companies, such as Microsoft and Xerox, as well as government institutions, such as NASA and the White House. However, there are also examples of it being used for public activities in other countries. For instance, the police of Western Australia who have jurisdiction of over 2.5 million square kilometres have used this tool to find ideas to increase their effectiveness in the face of a growing population of inhabitants. A team of officers were set up to organise and implement the initiative. Cinema tickets were used as an incentive to participate in the initiative. The response from the police officers working in the region was significant (Western Australia Police, 2015). Imaginatik is a piece of software that supports commercial innovation processes. It offers three modules - for creating, improving and evaluat- 
ing ideas. The combined package of this software covers the entire process of managing innovations, starting with the gathering of ideas, passing through their development and testing, and ending with product implementation. Users are encouraged to submit ideas in response to the challenges/initiatives. Participation in discussion and assessment is rewarded with 'kudos' points. Each user has their own profile which shows the areas of their expertise based on the number of points scored. This makes it easy to find substantive experts in specific fields and ask them personally to join a specific initiative. Thanks to advanced analytical tools, ideas are evaluated and prioritised.

\section{Discussion}

The intention behind the proposed IT platform supporting the process of creating social innovations was to create an open, collaborative space where the sharing of information and joint generation of knowledge would integrate the community. Thanks to the implementation of such a solution, it is assumed that several mutually complementary objectives will be achieved. The first is to improve quality, but it is equally as important to strengthen civic attitudes and deepen the inhabitants' identification with the region. In addition, a culture of innovation is expected to grow through the undertaking of social initiatives.

\subsection{Assumptions about the features of the platform supporting social innovation processes}

An analysis of the functioning of platforms aimed at supporting innovation processes led to the formulation of assumptions for the developed concept of the platform supporting social innovation processes.

1. It should provide the widest possible group of the region's inhabitants with an opportunity to get involved.

2. Not only should the exchange of knowledge concern the search for concepts of innovations, but also the identification of problems that can be solved in an innovative way.

3. Social innovations should be developed in areas where they are needed the most where there is the greatest knowledge of the specificities of the given problem. Therefore, it is assumed that key specific issues (problems) will be identified and related to a specific territorial area. 
4. The platform is to enable cooperation between citizens and local government at all development stages of the innovation process.

5. Users should see the effects of their involvement relatively quickly. They should identify with the idea that they produced as well as support and monitor its development.

6. Involving experts in the discussion increases the substantive value of the discussion and the resulting concepts of solutions to problems. It also motivates users to share knowledge and seek valid arguments for or against the proposals presented.

7. The platform should be managed by a public organisation, not a private one because of possible suspicions of manipulation of opinions and voting results.

8. Citizens should be able to express themselves without making their identity public. However, the identity of all users should be verifiable to an extent allowing reaction to unethical behaviour.

9. Those speaking on behalf of public organisations and institutions should do so completely openly.

10. Excessive restrictions in the terms and conditions of submitting proposals reduce the functionality of the platform and are ineffective due to, among other things, difficulties in verification.

11. The platform should be equipped with mechanisms of smart searching for problems and concepts.

12. Mechanisms should be put in place to analyse and evaluate users' activity and involvement in terms of the knowledge they contribute (identification of experts).

Based on the developed assumptions, the structure and procedures for management of the IT platform were proposed. This is the initial phase of work on the project for the development of social innovation in the region.

\subsection{Proposed structure of the platform supporting social innovation processes}

The proposed concept is based on the collective intelligence model and crowd voting. The platform is planned to operate at three interlinked levels (Figure 3): local, regional and national. The essence of the proposal for such a structure is the gradual development of social innovations according to the model discussed in section 2.1. It stipulates that the needs are the source of social inno- 
vation. Their identification is entrusted to local communities which have the greatest knowledge of the problems of everyday life. At the local level, initial ideas for solutions to existing problems should also appear and be tested. Solutions that are the most promising and relevant to the needs of a larger community should be transferred to the regional level where the innovations, implemented on a pilot basis, are assessed for their usefulness to a wider group of beneficiaries. It is assumed that only the positively assessed and tested solutions will be transferred to the national level of the platform which corresponds to the fifth and sixth stages of the innovation processes development model (Section 2.1). The innovations considered there must therefore have the potential for systemic change. The proposed procedure assumes a gradual development of social innovation. This is supposed to streamline expenditure through a progressive increase of the funds involved. Thus, the largest expenditure will be allocated to social innovations with the greatest potential for success understood by the ratio of change in the inhabitants' quality of life to expenditure allocated for this purpose.

One of the strong points of the open innovation concept is the participation of various environments in the creation of knowledge. Therefore, in order to support social innovation processes, the use of the involvement of social leaders is proposed. The task of these people - representatives of public institutions - is to provide support and expert evaluation of proposals submitted through the IT platform. Such a procedure will provide users with substantive assistance related to, e.g. legal limitations or organisational possibilities for implementing specific innovations. Moreover, it will help to show citizens the degree of involvement in social activity of people who perform public functions. At each successive level, support through other institutions and their representatives is proposed (Figure 3). At the local level, these are local government officials, as well as teachers and managers of local sports and cultural centres. At the regional level - people responsible for governing the province, members of regional councils, as well as representatives of secondary schools and university faculty boards. At the national level, these are ministers, members of parliament and representatives of national institutions. 


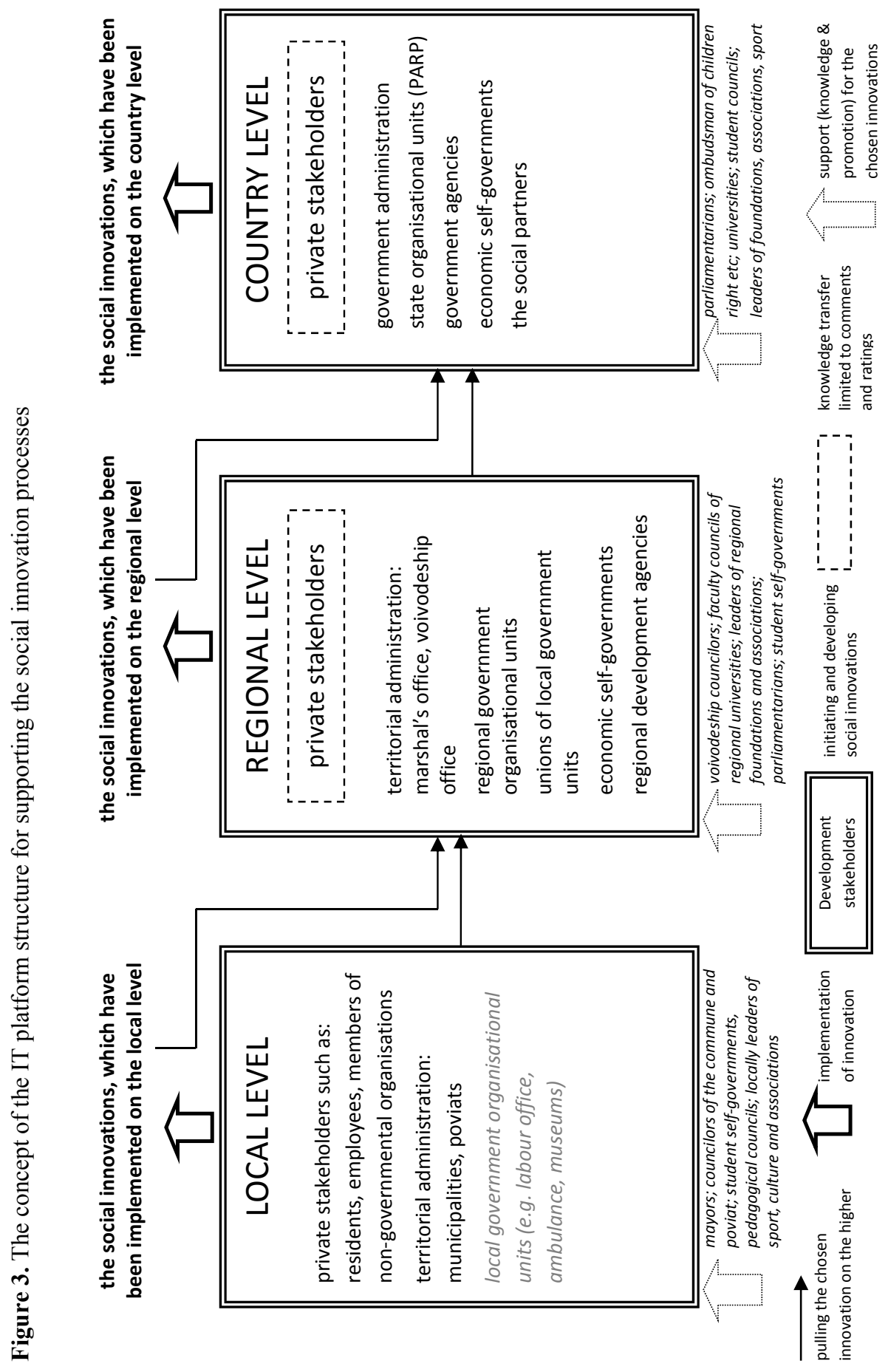


The concept of the IT platform assumes gradual development of social innovations from the local level up to the national level. However, additional sources of innovation are proposed to be introduced at regional and national levels. They make it possible to shorten the innovation process, but this path is to be reserved only for institutions whose core activity is to seek and implement solutions to problems at higher levels. For example, at the regional level, these include organisations, agencies, foundations and other regional unions, and at the national level - socio-economic partners, i.e. the Business Centre Club, the Trade Unions Forum, the Lewiatan Confederation, the 'Solidarity' Independent Self-governing Labour Union, and the All-Poland Alliance of Trade Unions.

One of the most serious problems with the functioning of crowdsourcing platforms focused on knowledge creation is the involvement of a proper number of users. The concentration of crowd knowledge and experiences is the basis for creating new value through the effect of synergy. Considering the results of a review of existing IT platforms, the following solutions are proposed to be implemented:

- acquisition of knowledge on a specific issue by conducting thematic campaigns lasting from several days to a couple of weeks,

- participation of experts and reputable persons in discussions on specific issues, e.g. athletes in discussions on sports education,

- awarding points to users for actions taken, e.g. evaluation of a concept, leaving a comment and, above all, introduction of their own idea.

The most important element of the concept of the IT platform supporting the creation of social innovations is to ensure efficient exchange of knowledge. It is therefore proposed that regions should be grouped by their specific circumstances. Inhabitants of the region who know specific problems in their area often understand the different circumstances better than political officials at the central level. For example, the pressing social issues in the Opole Province are: migration, functioning of public transportation, development of the national minority's culture. Solutions in this scope developed in one region could be imitated in another where a smaller part of the community is affected. A similar dependence will also exist at the level of municipalities and counties, which is why the platform should enable an exchange of knowledge on particular solutions. This is done by smart search mechanisms which, taking into account the diversity of forms of content transmitted, must use processes based on semantic networks. However, the functionality of the platform will not depend solely on the IT solutions used. The procedures for accessing the platform and the way in which it is 
implemented will be equally as important. This requires the involvement and participation of local authorities as well as their understanding of the possibilities of using the knowledge created by an information society for the development of the region.

\section{Conclusions}

The purpose of the presented paper was to develop a tool intended for the stimulation of the climate of innovation in the region. It was assumed that the means of achieving this goal was to orientate the cooperation of the local community toward the creation of original concepts of solutions that responded to their real needs. Research shows that many companies successfully use IT platforms in innovation process supporting. There are also examples of participation in public management via the Internet. Based on these experiences, the concept of an original IT platform was proposed. The idea of the solution is to cover the whole social innovation process by introducing three connected levels: local, regional and national. The functionality of each level has to correspond with the knowledge development in the social innovation model. This will enable the participation of a broader community in decision-making processes and thus increase the amount of available knowledge and strengthen the community's identification on local, regional and national levels.

\subsection{Research contribution}

The idea of knowledge exchange through the IT platform is known. However, the paper contains specific indications concerning social innovations and propositions to encourage citizen participation. The experience of many IT platforms supporting innovation through the use of crowdsourcing shows that an IT solution itself does not determine the success of an undertaking. We have emphasised the crucial role of incentives in people's engagement. Involvement and exchange of knowledge will intensify the life conditions development. It should enable social recognition and self-fulfilment of the individuals and social groups involved in social innovation implementation. It will also increase the level of identification with the local community. The Polish specificity concerning the presented concept of the platform was taken into account through the structure of the administrative division into communes, counties, and provinces. However, a similar structure can be found in many countries. 
The contribution of the paper to the literature is the linking of the social innovation process model with the use of IT tools. Furthermore, the paper includes an emphasis on the importance of linking regional development with local initiatives. It also raises the problem of creative implementation of the best practices used at local and regional levels at the national level. It furthermore indicates new opportunities for developing a participative model through the use of IT tools.

\subsection{Implications for scientists and practitioners}

The implementation of new technologies in supporting civil dialogue provides to make the traditional communication processes with citizens more attractive. Bilateral communication means that local authorities can gain knowledge about the needs and preferences of citizens. However, the use of the Internet should encourage the bottom up mobilisation of citizens for their engagement in region development.

These issues are important for the local government administration and social leaders, but also for researchers dealing with the topic of using IT tools in management.

One of the major problems is assessing the quality of participation in the context of knowledge possession, the ability to communicate, and skills in arguing by both sides of the dialogue. This type of research can be carried out by analysing the use of online platforms, such as Idea Scale, in social campaigns.

\subsection{Limitation and future work}

The Internet platform proposed in the paper supporting the development of social innovations is at the concept stage. Initial research based on observation has been carried out. Further work requires more structured research based on quantity research methods. Each of the indicated assumptions for the platform should be discussed in terms of possible solutions and next assessed in terms of expectations of future users.

For deeper research, the concept must first be improved to the form of a prototype. Therefore, in further works, it is planned to elaborate on the platform's concept in enough detail to allow for studies on its implementation to be carried out. The establishment of the factors determining its acceptance is in- 
tended by the authors at an early stage as the basis for designing detailed solutions, such as the moderation of discussions, filtering of results and their visualisation, etc. Another important issue seems to be the search for ways to promote social involvement. Moreover, there are plans to develop an ontology of social innovations, forming the basis for a semantic network allowing for the management of knowledge in the platform as a whole. These studies should be conducted in conjunction with the observation of the development of the use of online platforms in a social and economic environment.

\section{References}

Acik, N. (2013). Reducing the participation gap in civic engagement: Political consumerism in Europe. European Sociological Review, 29(6), 1309-1322. https:// doi.org/10.1093/esr/jct016

Anderson, N., Potočnik, K., \& Zhou, J. (2014). Innovation and creativity in organizations: A state-of-the-science review, perspective, commentary, and guiding framework. Journal of Management, 40(5), 1297-1333. https://doi.org/10.1177/01 49206314527128

Bates, S. (2012, March). The social innovation imperative. Stanford Social Innovation Review. Retrieved from http://www.ssireview.org/papers/entry/the_social_ innovation_imperative

Blazevic, V., \& Lievens, A. (2008). Managing innovation through customer coproduced knowledge in electronic services: An exploratory study. Journal of the Academy of Marketing Science, 36(1), 138-151. https://doi.org/10.1007/s11747-007-0064-y

Chesbrough, H. (2012). Open innovation - where we've been and where we're going. Research Technology Management, 55(4), 20-27. https://doi.org/10.5437/0895 $6308 \times 5504085$

Doan, A., Ramakrishnan, R., \& Halevy, A. Y. (2011). Crowdsourcing systems on the world-wide web. Communications of the ACM, 54(4), 86-96. https://doi.org/ $10.1145 / 1924421.1924442$

Estensoro, M. (2015). How can social innovation be facilitated? Experiences from an action research process in a local network. Systemic Practice \& Action Research, 28(6), 527-545. https://doi.org/10.1007/s11213-015-9347-2

Fagerberg, J. (2004). Innovation: A guide to the literature. In J. Fagerberg, D. Mowery, \& R. Nelson (Eds.), The Oxford handbook of innovation (pp. 1-26). Oxford: Oxford University Press. https://doi.org/10.1093/oxfordhb/9780199286805.001.0001

Foote Whyte, W. (Ed.). (1991). Participatory action research (Sage Focus Edition). Newbury Park, CA: Sage. https://doi.org/10.4135/9781412985383

Gilman, H. R. (2016). Participatory budgeting and civic tech: The revival of citizen engagement. Washington: Georgetown University Press. 
Grimm, R., Fox, Ch., Baines, S., \& Albertson, K. (2013). Social innovation, an answer to contemporary societal challenges? Locating the concept in theory and practice. Innovation. The European Journal of Social Sciences, 26(4), 436-455. https://doi. org/10.1080/13511610.2013.848163

Howaldt, J., Kopp, R., \& Schwarz, M. (2015). On the theory of social innovations: Tarde's neglected contribution to the development of a sociological innovation theory. Weinheim: Beltz Juventa. Retrieved from https://www.ssoar.info/ssoar/ bitstream/handle/document/41963/ssoar-2015-howaldt_et_al-On_the_theory_of_ social.pdf? sequence $=1$

Irvin, R. A., \& Stansbury, J. (2004). Citizen participation in decision making: Is it worth the effort? Public Administration Review, 64(1), 55-65. https://doi.org/10.1111/ j.1540-6210.2004.00346.x

Kaplan, A. M., \& Haenlein, M. (2010, January-February). Users of the world, unite! The challenges and opportunities of social media. Business Horizons, 53, 59-68. https://doi.org/10.1016/j.bushor.2009.09.003

Łabędź, K. (2016). Aktywność obywatelska na poziomie lokalnym i jej determinanty (na przykładzie Krakowa). [Civic engagement at the local level and its determinants (the example of Krakow)]. Polityka $i$ Spoleczeństwo. Studies in Politics and Society, 4(14), 19-35. https://doi.org/10.15584/polispol.2016.4.2

Mulgan, G. (with Tucker, S., Ali, R., \& Sanders, B.). (2007). Social innovation - what is it, why it matters and how it can be accelerated. London: The Young Foundation.

Murray, R., Caulier-Grice, J., \& Mulgan, G. (2010). The open book of social innovation. London: Nesta.

O'Faircheallaigh, C. (2010, January). Public participation and environmental impact assessment: Purposes, implications, and lessons for public policy making. Environmental Impact Assessment Review, 30(1), 19-27. https://doi.org/10.1016/ j.eiar.2009.05.001

Olejniczuk-Merta, A. (2015). Social innovations in the process of system products development. Journal of Economics and Management, 22(4), 5-15.

Peter-Bombik, K., \& Szczudlińska-Kanoś, A. (2015). Participatory management in local communities, Prace Naukowe Uniwersytetu Ekonomicznego we Wroctawiu. Research Papers of Wroclaw University of Economics, 391, 83-91. https://doi.org/ 10.15611/PN.2015.391.08

Phills, J. A. Jr., Deiglmeier, K., \& Miller, D. T. (2008, Fall). Rediscovering social innovation. Stanford Social Innovation Review, 6(4), 34-43.

Rawhouser, H., Cummings, M., \& Newbert, S. L. (2019). Social impact measurement: Current approaches and future directions for social entrepreneurship research. Entrepreneurship Theory and Practice, 43(1), 82-115. http://doi.org/10.1177/ 1042258717727718

Saebi, T., Foss, N. J., \& Linder, S. (2019). Social entrepreneurship research: Past achievements and future promises. Journal of Management, 45(1), 70-95. https:// doi.org/10.1177/0149206318793196 
Sankowska, A. (2016). Trust, knowledge creation and mediating effects of knowledge transfer processes. Journal of Economics and Management, 23(1), 33-44.

Sobol, A. (2015). Governance and citizens' engagement in terms of local sustainable development. Journal of Economics and Management, 19(1), 63-76.

Surowiecki, J. (2004). The wisdom of crowds: Why the many are smarter than the few and how collective wisdom shapes business. New York: Anchor Books. Retrieved from http://www.asecib.ase.ro/mps/TheWisdomOfCrowds-JamesSurowiecki.pdf

Szewczuk-Stępień, M., Adamska, M., \& Klemens, B. (2017). Strategie oddziaływania na interesariuszy rozwoju lokalnego kierowanego przez społeczność [Strategies of impact on stakeholders of local community development leads by the citizens]. In H. Brandenburg \& P. Sekuła (Eds.), Projekty lokalne i regionalne - interesariusze projektu [Stakeholders of local and regional projects] (pp. 340-353). Katowice: Wydawnictwo Uniwersytetu Ekonomicznego w Katowicach.

Tidd, J., \& Bessant, J. (2013). Managing innovation: Integrating technological, market and organizational change (5th ed.). Chichester, West Sussex: Wiley.

Tomlinson, Ph. R. (2010). Cooperative ties and innovation: Some new evidence for UK manufacturing. Research Policy, 39(6), 762-775. https://doi.org/10.1016/j.respol. 2010.02.010

Wenger, E. C., \& Snyder, W. M. (2000, January-February). Communities of practice: The organizational frontier. Harvard Business Review, 78, 139-145.

Western Australia Police. (2015). Case study. Retrieved from https://ideascale.com/wpcontent/uploads/2015/06/WAPOL2.pdf 